\title{
THE BOUNDARIES OF THE INTERNAL MARKET AFTER THE LISBON TREATY: A CLOSER LOOK AT ARTICLE 95 EC
}

\begin{abstract}
Isidora Maletić
Summary: The present paper aims to explore the boundaries of EU law following the Lisbon Treaty with specific regard to the internal market. Over fifty years since its inception, the underlying promise of the creation of an internal market remains a key parameter to test the progress of European integration. A constituent aspect of the $\mathrm{Eu}$ ropean legislative agenda, the exact boundaries of a continually developing internal market have to date remained fluid and contested. This is readily exemplified by considering a provision situated at its heart, Article 95 EC, which enables Community institutions to adopt measures intended to promote the establishment and functioning of the internal market. It is notable that, despite initial suggestions to this effect, the pivotal Article $95 \mathrm{EC}$ has been little altered by the Lisbon negotiations. Article 95 EC represents an important constitutional compromise between the ever-increasing Community competences and the regulatory autonomy of Member States, as well as between the often-conflicting interests of economic progress and welfare protection. This study will revise the complex Article 95 paradigm and outline some of the possible challenges facing this fundamental field in the aftermath of the Lisbon Treaty. Revisiting one of the key historical objectives of the European integration project would not only be conducive to greater determinacy in this specific field, but could offer a basis for a broader discussion of what values should characterise the European Union going forward. As the challenges following Lisbon are crystallising, there would appear to be no better time to revisit the strategy to be adopted in the continued pursuit of the effective establishment and functioning of the internal market.
\end{abstract}

\section{The boundaries of the internal market}

There are two sets of boundaries in the context of the internal market that deserve to be highlighted for the purposes of this study. The first reason is that the boundaries of the legislative competence of the Community, at least ever since the seminal Tobacco Advertising ${ }^{1}$ judgment,

\footnotetext{
" PhD candidate and tutor in European Union Law, King's College London. The present paper is based on the author's doctoral studies.

1 C-376/98 Germany $v$ Parliament and Council [2000] ECR I-2247.
} 
and arguably even before, have been disputed. The question therefore arises about what can be harmonised in the name of the internal market. Secondly, the exact scope of residual Member State autonomy following harmonisation remains undetermined, obfuscating the limits between Community competence and national regulation. In other words, once a harmonisation norm has been introduced, what are, in this new redefined market, the boundaries between Community action and residual national autonomy? Both questions can be answered by looking at a legislative tool that is central to the achievement of European integration in this context, Article $95 \mathrm{EC}$, which enables the Community legislature to adopt measures for the approximation of Member State provisions relating to the establishment and functioning of the internal market.

The question of Community competence, of what measures may be adopted for the purposes of harmonisation, is still, over 50 years since the inception of the European project, very much alive. Numerous challenges have been made to norms adopted on the basis of Article $95 \mathrm{EC}$ on the ground that these had been unlawfully adopted in the name of the internal market. In accordance with the principle of attributed powers contained within Article $5 \mathrm{EC}$ and the seminal Tobacco Advertising case, ${ }^{2}$ Article $95 \mathrm{EC}$ is not intended to confer on Community institutions unlimited regulatory powers, but rather to impart specific authority to pass legislation anticipated to facilitate the establishment and functioning of the internal market. Historically, however, the Article 95 EC brush has been used freely by Community institutions to paint the European legislative landscape. ${ }^{3}$ Recent rulings ${ }^{4}$ have highlighted how comprehensively the expression 'measures for the approximation' in Article 95 EC has been deployed, resulting in a wide range of Community regulations being adopted on this legal basis. The Tobacco Advertising saga, ${ }^{5}$ in particular, has tested the limits of European competence, suggesting that

2 C-376/98 Germany $v$ Parliament and Council [2000] ECR I-2247. In this important case, the Court annulled a Directive based on Article 95 EC, which had been allegedly adopted to promote the formation of the internal market, on the suspicion that the measure was intended, in reality, to harmonise rules governing public health, a matter which, as Article 152(4) of the Treaty explicates, lies beyond the Community's competence.

3 See for a discussion of these issues S Weatherill, 'Harmonisation: How Much, How Little?' (2005) 16 European Business Law Review 535.

4 See, for example, C-66/04 United Kingdom v Parliament and Council (Smoke Flavourings) [2005] ECR I-10553; C-436/03 European Parliament $v$ Council of the European Union [2006] ECR I-3733; C-217/04 United Kingdom $v$ European Parliament [2006] ECR I-3771. See, for a recent example on the reach of Article 95 EC, Case C-301/06 Ireland $v$ Parliament and Council (judgment of 10 February 2009).

5 Established jurisprudence includes cases like Case C-491/01 British American Tobacco (Investments) and Imperial Tobacco [2002] ECR I-11453; Case C-434/02 Arnold André [2004] ECR I-11825; Case C-210/03 Swedish Match [2004] ECR I-11893, and, perhaps most emphatically, C-380/03 Germany v European Parliament [2006] ECR I-11573. 
although European initiatives under Article 95 EC must relate to the establishment and functioning of the internal market, the provision will not be automatically unavailable in circumstances where policies other than strictly economic integration, such as public health considerations, may have encouraged the legislator to adopt a Community norm. ${ }^{6}$

As briefly outlined above, a related difficulty in defining the boundaries of the internal market concerns the scope for national residual autonomy following harmonisation. Indeed, the structure of Article $95 \mathrm{EC}$ would appear to be somewhat contradictory, thus making the search for the boundaries of the internal market a complex task. The vivid emphasis on Community competence to legislate, and the enabling language of the first part of Article $95 \mathrm{EC}$, are counterbalanced by the second half of this vital provision. Indeed, Article 95 EC also contains a derogation mechanism enabling Member States, under cautiously drafted circumstances, to derogate from a Community norm. Thus, following the adoption of a harmonisation measure, Member States may apply to maintain existing national provisions or even introduce new national provisions in order to safeguard specified national interests. ${ }^{7}$ The Commission is then under an obligation, within a specified period, to approve or reject the notified national provisions, after verifying if they constitute a means of arbitrary discrimination or a disguised restriction on trade between Member States and an obstacle to the functioning of the internal market. As a result, Article $95 \mathrm{EC}$ is characterised by, on the one hand, a strong integrationist impetus, and on the other, a national safety net enabling Member States to derogate from Community norms despite harmonisation efforts.

\footnotetext{
6 The generous Community paint strokes have undoubtedly been inspired at least in part by Article 95 EC itself, which recognises that the Commission, in its proposals on the establishment and functioning of the internal market concerning health, safety, environmental protection, and consumer protection, is to 'take as a base a high level of protection, taking account in particular of any new development based on scientific facts' (see paragraph 3 of Article $95 \mathrm{EC}$ ). The concern for the regulatory quality of legislative norms is reinforced by the 'horizontal' provisions, such as Articles 6, 153(2) and 152(1) EC, directing that environmental, consumer and health protection be considered in the implementation of Community policies. See Weatherill (n 3) 535.

7 Under paragraph 4 of Article 95, following the adoption of a harmonisation norm and subject to Commission approval, if it deems it necessary to do so, a Member State is in principle entitled to maintain existing national provisions on grounds of the major needs referred to in Article $30 \mathrm{EC}$, or relating to the protection of the environment or the working environment. The major needs referred to in Article 30 are 'public morality, public policy or public security; the protection of health and life of humans, animals or plants; the protection of national treasures possessing artistic, historic or archaeological value; or the protection of industrial and commercial property', which notably excludes consumer and environmental protection. Paragraph 5 of Article 95 EC provides for the further possibility following the adoption of a harmonisation measure of introducing new national provisions, but merely relating to the protection of the environment or the working environment.
} 
In view of the clear damaging potential to Community legislation and economic integration resulting from this derogation device, when first concocted in 1987 by the Single European Act, the provision was generally perceived as a retrograde step for the Community. The origins of this apparently radical mechanism lie in the concern expressed by some of the Member States at the time of the SEA, which introduced qualified majority voting in the context of the internal market, that this would entail decreased protection of certain national interests. The derogation mechanism has been seen as presenting 'real opportunities for protectionist

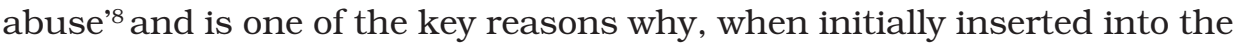
SEA, the latter legislation was regarded 'as an instrument of destruction'9 for what had already been achieved by the Community. Nevertheless, this notification procedure, encapsulated by paragraphs four to nine of Article $95 \mathrm{EC}$, 'has proved to be relatively infrequently invoked and its use even less frequently authorised'. ${ }^{10}$ Indeed, so limited has been the deployment of this derogation procedure in practice, and so expansive the breadth of the harmonisation programme under this provision, that it could be questioned whether the original constitutional compromise struck over the course of the SEA negotiations remains truly viable today.

A dilemma thus arises regarding, firstly, the limits of Community competence, and, secondly and concomitantly with this, the extent to which it is possible for Member States, following harmonisation of the internal market, to pursue different standards of regulatory protection of flanking policies, such as health or environmental protection. The first question, regarding the scope of Community competence, has often been raised in the academic literature and it will therefore only be explored in this study to the extent that it serves to facilitate discussion of the second, often neglected, aspect of Article 95 EC. Indeed, whilst it is clear from the Tobacco Advertising saga discussed above that the net of harmonisation under Article $95 \mathrm{EC}$ has been cast widely, the scope for residual national regulatory autonomy under this provision is less certain. ${ }^{11}$ Two recent rulings ${ }^{12}$ could help clarify the functioning of Article $95 \mathrm{EC}$ and reveal the

8 GA Bermann, 'The Single European Act: A New Constitution for the Community?' (19881989) 27 Columbia Journal of Transnational Law 543.

9 P Pescatore, 'Some Critical Remarks on the "Single European Act"' (1987) 24 Common Market Law Review 18.

10 S Weatherill, 'Supply of and Demand for Internal Market Regulation: Strategies, Preferences and Interpretation' in NN Shuibhne (ed), Regulating the Internal Market (Edward Elgar Publishing, Cheltenham 2006) 41.

11 Whilst the scope of Community competence for the purposes of the internal market under Article $95 \mathrm{EC}$ has been widely discussed, the related question of residual national autonomy has received comparatively little academic attention.

12 See further for the discussion of a related judgment, I Maletić, 'Toxic Substances and a Dangerous Procedure: An Analysis of Case T-234/04 Kingdom of the Netherlands v Commission' (2009) 36(1) Legal Issues of Economic Integration 75-82. 
potential implications of the legislative model adopted under this clause for the purposes of defining the boundaries of the internal market.

\section{Challenges for the internal market in the light of recent judicial developments}

The first case arose against the background of a 2001 Directive $^{13}$ on genetically modified organisms (GMOs) adopted on the basis of Article 95 EC. In 2003, hoping to obtain a derogation from the Community measure, Austria notified the Commission under Article $95 \mathrm{EC}$ of a draft law banning genetic engineering. The Austrian law was intended to prohibit the cultivation of seed and planting material containing GMOs and the breeding and release, for the purposes of hunting and fishing, of transgenic animals. In response to a request by the Commission for an analysis of the probative value of the scientific information relied on by Austria, the European Food Safety Authority, EFSA, issued an opinion, in which it essentially concluded that the information submitted did not contain any new scientific evidence that could justify banning GMOs. In the light of these findings, the Commission rejected Austria's request for derogation, ${ }^{14}$ concluding that the conditions in Article 95(5) EC had not been satisfied as Austria had failed to provide new scientific evidence or demonstrate that a specific problem in the Province of Upper Austria had arisen following the adoption of the relevant Directive that would have made it necessary to introduce the notified measure. Following the dismissal of the action brought by Austria seeking the annulment of the Commission decision before the CFI, ${ }^{15}$ Austria and the Province of Upper Austria initiated proceedings before the ECJ. In support of their appeal, they raised two pleas for annulment, alleging, first, infringement of the right to be heard and, second, infringement of Article 95(5) EC. The ECJ rejected both pleas and the action was dismissed. ${ }^{16}$

The second case arose against the background of an Article 95 EC application by the Netherlands, seeking to introduce a national norm for limiting emissions of particulate matter by diesel-powered vehicles that would have been stricter than the relevant Community norm. ${ }^{17}$ More spe-

13 Directive 2001/18/EC of the European Parliament and of the Council of 12 March 2001 on the deliberate release into the environment of genetically modified organisms and repealing Council Directive 90/220/EEC (OJ 2001 L 106, 1).

14 Commission Decision 2003/653/EC of 2 September 2003 relating to national provisions on banning the use of genetically modified organisms in the region of Upper Austria notified by the Republic of Austria pursuant to Article 95(5) of the EC Treaty (OJ 2003 L 230, 34).

15 Joined Cases T-366/03 and T-235/04 Land Oberösterreich and Austria v Commission [2005] ECR II 4005.

16 Case C-439/05 Land Oberösterreich v Commission [2007] ECR I-7141.

17 Directive 98/69/EC of the European Parliament and of the Council of 13 October 1998 relating to the measures to be taken against air pollution by emissions from motor vehicles 
cifically, the Netherlands contended that in view of the grave problems concerning air quality on its territory, it was necessary to pass a decree intended to ensure that only vehicles complying with stricter limits would be authorised. The Commission rejected the proposed national rule, ${ }^{18}$ arguing in particular that the Netherlands had failed to prove the existence of a specific problem in accordance with the Article 95 EC notification procedure. The CFI dismissed the action by the Netherlands seeking the annulment of the Commission decision. Before the ECJ, the Netherlands relied on two main grounds in its support. Firstly, it submitted that the Court of First Instance had misconstrued the duty of care and the duty to state reasons in Article $253 \mathrm{EC}$ in ruling that the Commission had not breached those obligations by failing to take into account all available information. Secondly, the Netherlands argued that the Court of First Instance applied incorrect legal criteria to determine the existence of a specific problem of ambient air quality. The ECJ decided to set aside the judgment of the Court of First Instance and to annul the Commission Decision on the procedural basis that the Commission had failed to take into account crucial evidence in reaching its conclusion. ${ }^{19}$

As exemplified by the above rulings, the balance between Community competence and residual national regulatory autonomy under Article $95 \mathrm{EC}$ seems to have often shifted in favour of the rigorous protection of Community norms, with Member State applications being only rarely allowed. Thus, in the later emissions case, it is noteworthy that the Netherlands was seeking to pass a measure protecting the environment, an

and amending Council Directive 70/220/EEC (OJ 1998 L 350, 1). The Netherlands sought to set a limit value of $5 \mathrm{mg}$ per $\mathrm{km}$ for the emission of fine particulate matter for new dieselpowered passenger cars and diesel-powered commercial vehicles, as against the Community limit value of $25 \mathrm{mg}$ per $\mathrm{km}$.

18 Commission Decision 2006/372/EC of 3 May 2006 rejecting draft national provisions notified by the Kingdom of the Netherlands under Article 95(5) of the EC Treaty laying down limits on the emissions of particulate matter by diesel-powered vehicles (OJ 2006 L 142, 16).

19 In the view of the ECJ, since the Commission, in order to ascertain whether there was a specific problem of ambient air quality in the Netherlands, had not examined all the relevant data, its determination was necessarily vitiated by an error [C-405/07 Netherlands $v$ Commission (judgment of 6 November 2008) para 73]. There was accordingly no need to consider the second ground of appeal, namely that incorrect legal criteria had been applied in the determination of whether there was a specific problem of ambient air quality within the meaning of Article 95(5) EC such as to justify the purported derogation (para 75 of the judgment). In concluding that the contested decision had to be annulled so that the Commission would assess again the national measure, the ECJ did however suggest that 'the Commission's incomplete analysis of the relevant scientific evidence is apt to vitiate not only its determination as to whether there was a specific problem but the entirety of its determination of the conditions for applying Article 95(5) and (6) EC, and, particularly, that of the proportionality of the measure notified, since a fuller evaluation of the available scientific evidence may, by its very nature, affect the determination as to such a measure's proportionality' (para 77 of the judgment). 
interest that the Community itself strives to uphold, and that it cited as one of the reasons for the purported derogation the existence of another Community norm, Directive 1999/30/EC, ${ }^{20}$ which introduced limits on concentrations of particulate matter in ambient air and directed Member States to take all measures necessary to ensure that these limits were not exceeded. ${ }^{21}$ In addition, at the time when the Netherlands tried to introduce more restrictive grounds, there had already been a proposal for a Regulation limiting the emissions from vehicles: the 'Euro 5' Proposal, ${ }^{22}$ adopted by the Commission in December 2005, lowering to $5 \mathrm{mg} / \mathrm{km}$ the Community limit of $25 \mathrm{mg} / \mathrm{km}$ on emissions of particulate matter by diesel vehicles. The new Community limit was expected to enter into force at the end of September 2009 in respect of new types of vehicles in specified categories and, at the end of January 2011, for all new vehicles covered. However, the Netherlands wished to advance, at the national level, the introduction of the limit of $5 \mathrm{mg} / \mathrm{km}$, emphasising that, due to the country's high demographic density and a greater concentration of infrastructure than in other European States, particulate matter represented for it a cause of major concern. The national draft decree, which would have in effect constituted a temporary measure, was thus merely intended to advance a limit on emissions actually acknowledged as necessary by the Community itself. Nevertheless, despite these favourable circumstances surrounding the Member State application, the derogation request was ultimately rejected by the Commission.

\footnotetext{
20 Council Directive 1999/30/EC of 22 April 1999 relating to limit values for sulphur dioxide, nitrogen dioxide and oxides of nitrogen, particulate matter and lead in ambient air (OJ 1999 L 163, 41). Directive 2008/50/EC of the European Parliament and of the Council of 21 May 2008 on ambient air quality and cleaner air for Europe (OJ 2008 L 152, 1) is intended to replace Directives 96/62 and 1999/30 from 11 June 2010. Under Article 22(2) of Directive 2008/50, where, in a given zone or agglomeration, conformity with the specified limit values for PM10 cannot be achieved because of site-specific dispersion characteristics, adverse climatic conditions or transboundary contributions, a Member State is, subject to the fulfilment of certain conditions, to be exempt until 11 June 2011, from applying those limit values.

21 The Netherlands submitted in particular that the limits on concentrations of particulate matter set out by the Directive were exceeded in several areas of its territory. Consequently, it did not consider itself in a position to comply with its Community obligations. As noted by the Advocate General, 'the problem which the Netherlands seeks to counter by securing a derogation from Directive 98/69 lies in the requirements of other provisions of Community law: the ambient air in the Netherlands does not achieve the state stipulated in Directive 96/62 in conjunction with Directive 1999/30' (Opinion of Advocate General Kokott of 17 July 2008 Case C-405/07 Netherlands $v$ Commission para 83).

22 Regulation (EC) No 715/2007 of the European Parliament and of the Council of 20 June 2007 on type approval of motor vehicles with respect to emissions from light passenger and commercial vehicles (Euro 5 and Euro 6) and on access to vehicle repair and maintenance information (OJ $2007 \mathrm{~L} 171,1$ ) are due to replace Directives 70/220 and 98/69 from 2 January 2013.
} 
Care should be taken not to draw prematurely a definitive conclusion on the significance of the cases for the task of deciphering the boundaries following harmonisation between Community competence and residual national autonomy within the internal market. Indeed, the Article $95 \mathrm{EC}$ notification procedure has been invoked in a somewhat uncertain manner by the Member States, with cases often revolving, and national applications frequently failing, on procedural grounds. ${ }^{23}$ With respect to the case on genetic engineering, for example, the final outcome may have been largely instigated by the fact that it concerned an attempt by one of the Austrian Länder to introduce, with a view to creating a farming area free of GMOs, a law imposing a general ban, whereas under the relevant Community measure, the placing on the market of a GMO was subject to an authorisation regime requiring a health and environmental risk assessment on a case-by-case basis. Rather than being necessarily reflective of a narrow reading of the procedure contained within Article $95 \mathrm{EC}$ and a perceived limited scope for national regulatory autonomy within the internal market, the case could merely be in line with the application of the principle of proportionality in the context of negative integration where, in the absence of harmonisation norms, national measures purporting to introduce blanket bans have often been condemned by the Courts. ${ }^{24}$ Before proceeding to a fuller evaluation of the extent to which harmonisation under this provision, which characterises much of the European legislative agenda, may be reconciled with regulatory variation at national level, it is necessary to examine more closely the purported effects of the Treaty of Lisbon on the boundaries of the internal market.

\section{Revisiting the boundaries of the internal market following Lisbon}

Despite the considerable discussion concerning possible reforms of Article 95 EC, especially with regards to the scope of Community competence under this provision, the alterations ultimately agreed to have been relatively modest. The Treaty does purport to make some changes in the field of the approximation of laws. In particular, the important relationship between Articles 94 EC and 95 EC, as reflected by the suggested reversed order of the provisions, has been reviewed. Article 95 EC was traditionally drafted as a residual clause, to be used by way of derogation from Article 94 EC, which requires unanimity. The Lisbon Treaty, highlighting the increased use of QMV for the completion of the internal market and reflecting how generously the provision has been used, clarifies that Article 95 EC should no longer be deployed by way of derogation

23 See, for example, Case C-512/99 Germany v Commission [2003] ECR I-845; Case T234/04 Netherlands $v$ Commission (judgment of 8 November 2007).

24 See, for an early example, Case 178/84 Commission v Germany [1987] ECR 1227. 
from the current Article 94 EC. Nevertheless, despite these modifications, it will be readily seen that the somewhat contradictory paradigm of Article $95 \mathrm{EC}$, with a strong integrationist impetus on the one hand, and the cautious preservation of residual national autonomy on the other, has largely been left unaltered by the recent Lisbon Treaty. ${ }^{25}$ The boundaries of the internal market, both in terms of the actual scope of Community competence and the division of regulatory powers following harmonisation within the context of Article $95 \mathrm{EC}$, will remain as contested as ever, even after the Lisbon negotiations.

It may be expected, then, that the Commission and the Courts will thus continue to have an onerous task and crucial role in administering the boundaries between Community competence and residual national autonomy for the purposes of the effective establishment and functioning of the internal market. As aforementioned, at least some alterations were sought to be made by the Treaty of Lisbon with respect to the approximation of laws field. Perhaps, in this respect, it would be plausible to interpret the decision to leave the essence of Article $95 \mathrm{EC}$ intact as tacit acceptance that the harmonisation model typifying the provision is perceived to be a fundamentally workable one. In this view, it would be left in particular to the Commission under the notification procedure and the Courts in cases before them, by pursuing a balance between the often contrasting currents of market integration and residual Member States regulatory variation, to minimise the opportunities for competence creep and to allow Member States exceptionally to derogate from attained Community standards. As aforementioned, Article 95 EC could be seen as encapsulating a vital constitutional compromise between the ever-increasing Community powers and the residual regulatory autonomy of Member States, as well as a possible reconciliation between the oftenconflicting interests of economic progress and related welfare policies. Given these clashing aims, the present, somewhat contradictory, nature of the clause might not appear altogether surprising. Following the Treaty of Lisbon, one of the key challenges for the Commission and the Courts, in particular within the context of the internal market, will be to find a balance between these underlying objectives.

The heavy burden on applicant Member States ${ }^{26}$ seeking to derogate from a harmonisation norm on the basis of Article 95 EC is perhaps

25 The Lisbon Treaty does, however, purport to give greater force to the principle of subsidiarity. See, for an exhaustive discussion of the proposed changes and their potential implications, M Dougan, 'The Treaty of Lisbon 2007: Winning Minds, not Hearts' (2008) 45 Common Market Law Review 617-703.

26 Under Article 95(5) EC, it is clear that the introduction of new national provisions derogating from a harmonisation measure must be based on new scientific evidence relating to the protection of the environment or the working environment made necessary by reason 
understandable given the fundamental objective of integration that this clause epitomises. The possibility provided by the notification procedure to deviate from harmonisation norms arises in the context of the internal market, so a conservative interpretation is to be expected. At the same time, however, a narrow application of this derogation mechanism in practice, either through improper or negligible use of the Member States or through a strict interpretation of the Commission and Courts, casts doubt on whether the current model of harmonisation encapsulated by the provision is truly congruent with the initial guarantee provided by the SEA to retain the possibility for national regulatory variation following harmonisation as a concession for the introduction of qualified majority voting within this field. An almost systematic rejection of Member State applications to maintain or introduce more stringent national measures following harmonisation could further undermine the possibility for the Community to respond promptly to emerging scientific challenges in the context of the internal market. As has been acknowledged by the CFI, ${ }^{27}$ the derogation mechanism under Article $95 \mathrm{EC}$ 'constitutes an adjustment to the organisation of the common market introduced for the purposes of preserving personal living and working conditions in the Community, an objective of the Treaty just as fundamental as that of the harmonisation of laws'. ${ }^{28}$ Although unilateral national rules may not be authorised lightly because, forming a clear derogation from negotiated harmonisation norms, they will frequently be directed, such as in the emissions case seen above where the Netherlands wanted to anticipate a measure approved in principle also at the Community level, towards interests like environmental protection that the Community itself seeks to protect. In such circumstances, if a Member State is authorised to maintain or introduce

of a problem specific to that Member State arising after the adoption of the harmonisation measure. These conditions are cumulative, so that all must be met for the derogating national measures to be allowed by the Commission. The case examined above on genetic engineering illustrates in particular the difficulty of proving the existence of a problem specific to the notifying Member State justifying a purported derogation. It is noteworthy that the ECJ emphasised that the lawfulness of national measures notified under Article 95(5) $\mathrm{EC}$ is closely linked to the assessment of the scientific evidence put forward by the notifying Member State.

27 Case T-182/06 Netherlands $v$ Commission [2007] ECR II-1983 (para 60).

28 The potential value of the notification procedure seems to have been accepted by the CFI, which explained that this 'applies, in particular, to cases where a new phenomenon arises in all or part of a Member State's territory, which has negative effects on the environment or the working environment and which could not be taken into account in the preparation of the harmonised rules and to which it is appropriate to apply a remedy at the outset at the national level, without waiting for an amendment to the Community legislation. Such an amendment could in fact be unsuitable to resolve the problem established, either because of the purely local nature of the phenomenon, or because of the particular characteristics which it exhibits locally and which are incompatible with the delays inherent in the negotiation and entry into force of new harmonised rules' (Case T-182/06 Netherlands $v$ Commission [2007] ECR II-1983 para 61). 
national provisions derogating from a harmonisation measure pursuant to the notification procedure contained within Article 95 EC, paragraph 7 of the same provision stipulates that the Commission is to examine immediately whether to propose an adaptation to that measure. Under the Treaty, therefore, the onus is placed on the Community to follow in the steps of individual States and to adapt in line with national scientific discoveries. An excessive presumption in favour of the harmonisation effort could, on the other hand, arguably result in harmonisation being perceived as an almost static process, so that it could be difficult for the derogation mechanism in paragraphs 4 to 9 of Article $95 \mathrm{EC}$ to inform attained legislation in line with scientific progress and national findings.

Ultimately, the interpretation adopted of the scope of the notification procedure under Article 95 EC raises more profound constitutional dilemmas concerning not only the breadth of Community competence to regulate the internal market, but also the form and quality of European harmonisation. The more the measures adopted for the purposes of the internal market are drafted as exhaustive measures sealing the possibility for Member States to invoke stricter national standards, the greater the emphasis on the derogation mechanism within Article 95 EC as an instrument of national regulatory variation, and the greater the emphasis on the quality of Community harmonisation. Nothing in Article 95 EC seems to suggest in a conclusive way a predilection for either minimum or maximum harmonisation as the preferred method of harmonisation for the purposes of the internal market. However, recent practice would seem to reflect an increasing trend towards exhaustive harmonisation. ${ }^{29}$ In this respect, examining in more detail the notification procedure under Article 95 EC may be particularly pressing and useful for drawing with greater certitude the boundaries between Community competence and national differentiation within the internal market following Lisbon. In the light of the defining character of Article 95 EC for the European legislative agenda, it would be desirable to reassess the overall functioning of the derogation mechanism contained therein. In particular, it may be opportune to consider the possibility of reform of the notification procedure, especially with reference to the accepted grounds on which Member States may rely to deviate from a harmonisation norm and the current time limits allowed for the Commission to reach a decision in response to an application for derogation. ${ }^{30}$ Assessing the advantages and shortcom-

29 See C-376/98 Germany $v$ Parliament and Council [2000] ECR I-8419; C-380/03 Germany $v$ European Parliament [2006] ECR I-11573. For a discussion, see Weatherill (n 10) 29-60; P Rott 'Minimum Harmonization for the Completion of the Internal Market? The Example of Consumer Sales Law' (2003) 40 Common Market Law Review 1107-1135.

30 It is clear from the jurisprudence of the ECJ that a Member State is not authorised to apply the national provisions notified by it under Article $95 \mathrm{EC}$ until after it has obtained a 
ings of the notification procedure contained within Article $95 \mathrm{EC}$ could in turn help to make a more informed decision as to what form harmonisation for the purposes of the European legislative process should take.

\section{Concluding observations}

Article 95 EC constitutes one of the most powerful instruments for the advancement of European harmonisation. It is clear that the legislative model under Article $95 \mathrm{EC}$ does not exist in isolation. The rulings of the ECJ, in the absence of common rules, have been fundamental to the process of European integration and have certainly served to move forward relentlessly the boundaries of the internal market. The wealth of jurisprudence on the fundamental freedoms will remain a key axiom in the delineation of the limits to the internal market. At the same time, however, while it is clear that a rigorous process of negative integration considerably reduces the need for positive harmonisation for the completion of the internal market, legislative harmonisation clearly remains a central instrument for the approximation of the laws of the Member States. ${ }^{31}$ In this respect, the unique paradox presented by Article 95 EC with, on the one hand, its broadly construed Community competence to advance economic integration, and, on the other, its preservation of national regulatory autonomy to further standards different from those attained at Community level on the basis of specified flanking policies, will present a key challenge in delineating the boundaries of the internal market, requiring the Community institutions and the Member States to revisit the contours of Community legislative competence in a field that will no doubt continue to represent, as much as historically, a useful parameter of the European integration process.

decision from the Commission (see Case C-41/93 France $v$ Commission [1994] ECR I-1829; Case C-319/97 Kortas [1999] ECR I-3143). Under paragraph 6 of Article 95, the Commission is under an obligation to reject or approve the national measures within six months. Furthermore, paragraph 6 also states that, when justified by the complexity of the matter and in the absence of danger for human health, the time allowed may be extended for a further period of up to six months.

31 As recognised by the Commission, 'Mutual recognition is not always a miracle solution for ensuring the free movement of goods in the single market. Harmonisation or further harmonisation remains without doubt one of the most effective instruments, both for economic operators and for the national administrations' (Commission Second biennial Report on the Application of the Principle of Mutual Recognition in the Single Market [COM (2002) 419]). 